\title{
TLR1 wt Allele
}

National Cancer Institute

\section{Source}

National Cancer Institute. TLR1 wt Allele. NCI Thesaurus. Code C52235.

Human TLR1 wild-type allele is located within $4 \mathrm{p} 14$ and is approximately $9 \mathrm{~kb}$ in length.

This allele, which encodes toll-like receptor 1 protein, plays a role in both pathogen

recognition and the activation of innate immunity to microbial agents. 